\title{
Effects of ammonium molybdate additive and sintering temperature on the properties of foam ceramics based on ceramic tile polishing waste
}

\author{
Cong WANG ${ }^{1}$, Weiwei CHEN ${ }^{1}$, Anze SHUI ${ }^{1}{ }^{\dagger}$, Jianqiao LI ${ }^{1}$, Wei TIAN ${ }^{1}$, \\ Juan MA ${ }^{1}$, Bin DU ${ }^{1}$ and Satoshi TANAKA ${ }^{2}$ \\ ${ }^{1}$ School of Materials Science and Engineering, South China University of Technology, Guangzhou 510641, China \\ ${ }^{2}$ Department of Materials Science and Technology, Nagaoka University of Technology, Nagaoka, Niigata 9402188, Japan
}

In this study, the foam ceramics based on ceramic tile polishing waste (CTPW) were successfully prepared by a simple solid phase sintering method. The CTPW was used as the main raw material, SiC inside CTPW as the foam agent and $\left(\mathrm{NH}_{4}\right)_{6} \mathrm{Mo}_{7} \mathrm{O}_{24}$ as the sintering additive. Effects of the amounts addition of $\left(\mathrm{NH}_{4}\right)_{6} \mathrm{Mo}_{7} \mathrm{O}_{24}\left(\mathrm{O}_{-6}\right.$ wt \%) and sintering temperature $\left(1080-1200^{\circ} \mathrm{C}\right)$ on the sintering properties, structural evolution, phase composition and mechanical properties have been investigated. During the sintering process, the SiC inside CTPW could react with oxygen and then produce the gases such as $\mathrm{CO}$ and $\mathrm{CO}_{2}$, which caused a closed-pore structure. After adding $\left(\mathrm{NH}_{4}\right)_{6} \mathrm{Mo}_{7} \mathrm{O}_{24}$ and increasing the sintering temperature, a better porous structure with suitable pore size and high compressive strength could be obtained. It was found that the foam ceramics doped with 2 wt $\%$ $\left(\mathrm{NH}_{4}\right)_{6} \mathrm{Mo}_{7} \mathrm{O}_{24}$ and sintered at $1200^{\circ} \mathrm{C}$ for $30 \mathrm{~min}$ showed excellent properties: a low bulk density $\left(0.362 \mathrm{~g} / \mathrm{cm}^{3}\right)$, the appropriate pore size $(0.94 \mathrm{~mm})$, a uniform pore size distribution and a very high compressive strength (8.16 MPa).

(2019 The Ceramic Society of Japan. All rights reserved.

Key-words : Foam ceramics, Ceramic tile polishing waste, Ammonium molybdate, Sintering temperature

[Received January 19, 2019; Accepted March 15, 2019]

\section{Introduction}

Porcelain tiles are widely applied in building materials due to outstanding properties such as high mechanical strength, wear and chemical resistance. And their very compact structure, vitrified throughout and extremely low porosity make the materials stain and frost resistant. ${ }^{1), 2)}$ In recent years, an increasing production of porcelain tiles has taken place in China according to a government report, which occupies more than half of overall production around the world. However, the porcelain tiles usually need to undergo the process of surface polishing to enhancing the aesthetical appearance of products. During this process, a relevant material with about $0.4-0.8 \mathrm{~mm}$ in thickness is removed from the tile surface, which creates a gloss surface level of $65-70 \%$. $^{3), 4)}$ As a result, it will generate a large amount of ceramic tile polishing waste (CTPW). It reported that the output of CTPW has reached about 6 million tons per year in China and it increases every year. ${ }^{5)}$ Commonly, the CTPW is collected and temporarily stored in effluent treatment stations. After removing the residual water and then it is generally disposed in landfill sites. However, the landfill treatment process not only occupies the massive land, but also wastes the

Corresponding author: A. Shui; E-mail: shuianze@scut. edu.cn mineral resource. ${ }^{6)}$ Thus, the recycling of CTPW is very important.

Recently, many researches have devoted their attention to recycling CTPW. Actually, the CTPW, generated by polishing process, mainly contains silica $\left(\mathrm{SiO}_{2}\right)$, aluminum oxide $\left(\mathrm{Al}_{2} \mathrm{O}_{3}\right)$ and bits of $\mathrm{Fe}_{2} \mathrm{O}_{3}, \mathrm{TiO}_{2}, \mathrm{~K}_{2} \mathrm{O}, \mathrm{Na}_{2} \mathrm{O}, \mathrm{CaO}$ and $\mathrm{MgO}$, which is similar to the ceramic material composition. ${ }^{5), 7)}$ For this reason, some reports indicated that it is feasible to use the CTPW to replace feldspar in ceramic industry or to manufacture traditional ceramic tiles. ${ }^{8)-10)}$ In addition, there are some other studies on the recycling of CTPW in concrete production to decrease the cost of production. ${ }^{6,11), 12)}$ However, the CTPW usually contains about $1-5 \mathrm{wt} \%$ silicon carbide (SiC) that derived from polishing tools. The $\mathrm{SiC}$ will react with oxygen and release gases such as $\mathrm{CO}$ and $\mathrm{CO}_{2}$ in a sintering temperature $\left(>1100^{\circ} \mathrm{C}\right)$ for the production of ceramic tiles. In this case, there are two problems with using the CTPW as a raw material for manufacturing traditional ceramic tiles: firstly, the generation of gas will hinder the process of sintering densification; secondly, the utilization rate of the CTPW is very low. Therefore, most studies have focused on preparing the porous or foam ceramics by using the CTPW as raw materials. 5),13)-16) At present, foamed ceramic is one of the most promising building insulation materials for its excellent advantages of chemically stable, low density, long-time stable in physical characteristics and water 
resistance. ${ }^{17)}$ Moreover, the foam ceramic as an insulation material is produced by using the CTPW as the raw material, which could reduce the environment pollution and lower the cost of production.

Most studies on preparing foam ceramics with CTPW needed to add additional foaming agent like $\mathrm{SiC}$, carbon ash or others. ${ }^{13), 15), 16)}$ It was reported that the CTPW usually contained about $1-5 \mathrm{wt} \% \mathrm{SiC}{ }^{5}$ ) The $\mathrm{SiC}$ inside CTPW may act as the foaming agent. However, the oxidation reaction of $\mathrm{SiC}$ inside the CTPW are closely related to the production and content of liquid phase. As shown in Fig. 1, the $\mathrm{SiO}_{2}$ envelope layer generally formed in the surface of $\mathrm{SiC}$, which prevented the contact of $\mathrm{SiC}$ and $\mathrm{O}_{2}$. And the diffusion rate of $\mathrm{O}_{2}$ in the $\mathrm{SiO}_{2}$ envelope layer was only $10^{-14}-10^{-15} \mathrm{~cm}^{2} / \mathrm{s}$. In order to increase the $\mathrm{O}_{2}$ diffusion rate and enable more $\mathrm{O}_{2}$ react with $\mathrm{SiC}$, the destruction of $\mathrm{SiO}_{2}$ envelope layer is very necessary. The $\mathrm{SiO}_{2}$ envelope layer could be destroyed by forming silicate liquid phase. However, the formation of silicate liquid phase usually required a higher sintering temperature in the sintering process of pure CTPW. Therefore, the use of the sintering aid is essential for getting the liquid phase in a lower sintering temperature in this study. Recently, the molybdenum oxides $\left(\mathrm{MoO}_{3}\right)$ have been used as one of sintering aid for reducing the sintering temperature in dielectric or electrolyte ceramics, ${ }^{18)-20)}$ co-fired ceramic ${ }^{21)}$ and porous ceramics. ${ }^{22}$ In optical glassy materials, $\mathrm{MoO}_{3}$ can also serve as a network former and a network modifier in the presence of glass formers such as $\mathrm{TeO}_{2}, \mathrm{P}_{2} \mathrm{O}_{5}$ and $\mathrm{B}_{2} \mathrm{O}_{3}$ based glasses. ${ }^{23)-26)}$ Moreover, some other researchers also reported that $\mathrm{MoO}_{3}$ addition cannot only lower the mullitization temperature but also be used as a catalyst to promote the formation of mullite whiskers. ${ }^{27)-29)}$

Therefore, in this study, the foam ceramics were prepared by using the CTPW as main material, not adding any additional foaming agent but only making the most of SiC in the CTPW. The ammonium molybdate $\left[\left(\mathrm{NH}_{4}\right)_{6} \mathrm{Mo}_{7} \mathrm{O}_{24}\right]$ was an important raw material for production and preparation of $\mathrm{MoO}_{3}{ }^{29)}{ }^{29}$,3) The $\mathrm{MoO}_{3}$ was achieved by the thermal decomposition of $\left(\mathrm{NH}_{4}\right)_{6} \mathrm{Mo}_{7} \mathrm{O}_{24}$ and was utilized as sintering aid and a catalyst in the sintering process, which caused the formation of liquid glassy phase at a lower temperature and promoted the production of mullite. Thus, the porous structure of the ceramic with good mechanical properties could be obtained. The foam ceramics with various amounts of $\left(\mathrm{NH}_{4}\right)_{6} \mathrm{Mo}_{7} \mathrm{O}_{24}$ ranging from 0 to $6 \mathrm{wt} \%$ were sintered at different temperature from 1080 to $1240^{\circ} \mathrm{C}$ for $30 \mathrm{~min}$. The effects of the amounts addition of $\left(\mathrm{NH}_{4}\right)_{6} \mathrm{Mo}_{7} \mathrm{O}_{24}$ and sintering temperature on the sintering properties, structural evolution, phase composition and mechanical properties of the foam ceramics were investigated in detail. The function mechanism of $\left(\mathrm{NH}_{4}\right)_{6} \mathrm{Mo}_{7} \mathrm{O}_{24}$ additive was also discussed.

\section{Experimental}

\subsection{Materials and experiment process \\ 2.1.1 Raw materials}

In this study, CTPW (Oceano Ceramics Co. Ltd., Guangdong, China) was the main raw material. The CTPW was first dried in drying oven at $100^{\circ} \mathrm{C}$ for $10 \mathrm{~h}$, and then dry-ball-milled in a planetary ball mill (QMISP4-CL, Instrument Plant of Nanjing University, China) for $2 \mathrm{~h}$ using alumina balls. The resulting powders were ground in an agate mortar and sieved through a 40-mesh sieve. The chemical composition of CTPW was shown in Table 1 and the phase composition of CTPW was seen in Fig. 2. It can be seen that the composition of CTPW was as follows: $\mathrm{SiO}_{2} 71.64 \mathrm{wt} \%, \mathrm{Al}_{2} \mathrm{O}_{3} 17.12 \mathrm{wt} \%, \mathrm{Fe}_{2} \mathrm{O}_{3}$ 0.56 wt $\%, \mathrm{TiO}_{2} 0.32$ wt $\%, \mathrm{CaO} 0.73$ wt $\%, \mathrm{MgO} 1.28$ wt $\%, \mathrm{~K}_{2} \mathrm{O} 1.75 \mathrm{wt} \%$, and $\mathrm{Na}_{2} \mathrm{O} 3.23 \mathrm{wt} \%$. The main phase in CTPW was quartz. There were also a few other phases such as amorphous phase, mullite and silicon carbide.

\subsubsection{Preparation of foam ceramics}

In this study, the ceramic tile polishing waste (as the main raw material) mixed with different content of $\left(\mathrm{NH}_{4}\right)_{6} \mathrm{Mo}_{7} \mathrm{O}_{24} \cdot 4 \mathrm{H}_{2} \mathrm{O}$ additive (purity $\geq 99.0 \mathrm{wt} \%$, Tianjin Chemical Reagent Factory No.4, Tianjin, China) were wetball-milled in a planetary ball mill (the weight ratio of

Table 1. The chemistry composition of CTPW (wt \%)

\begin{tabular}{ccccccccc}
\hline wt $\%$ & $\mathrm{SiO}_{2}$ & $\mathrm{Al}_{2} \mathrm{O}_{3}$ & $\mathrm{Fe}_{2} \mathrm{O}_{3}$ & $\mathrm{CaO}$ & $\mathrm{TiO}_{2}$ & $\mathrm{MgO}$ & $\mathrm{K}_{2} \mathrm{O}$ & $\mathrm{Na}_{2} \mathrm{O}$ \\
\hline $\mathrm{CTPW}$ & 71.64 & 17.12 & 0.56 & 0.73 & 0.32 & 1.28 & 1.75 & 3.23 \\
\hline
\end{tabular}

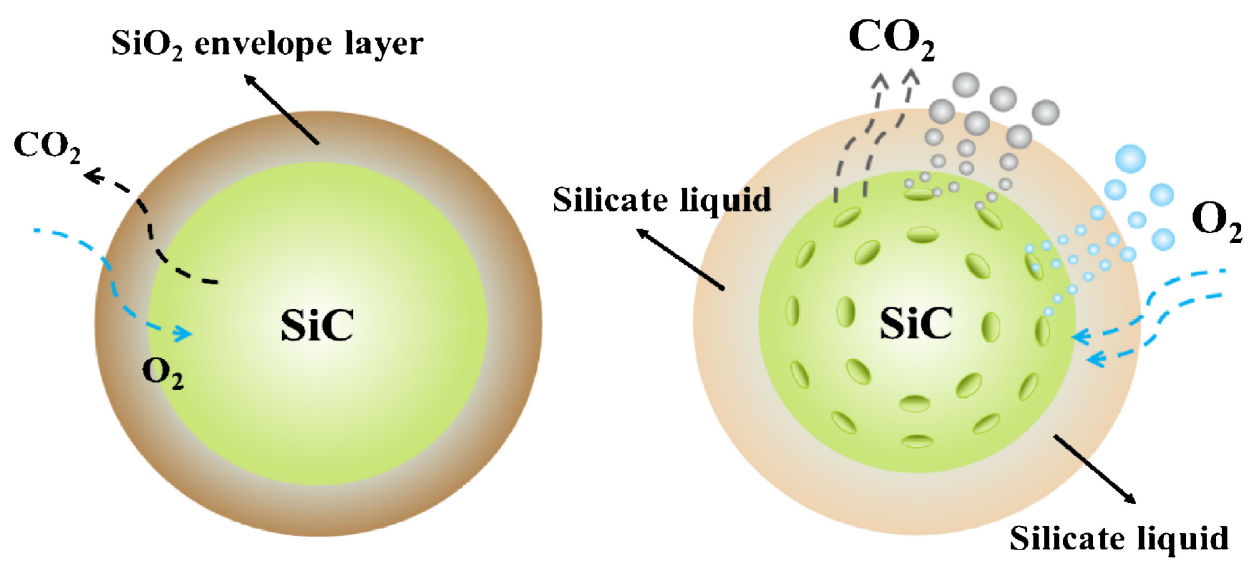

Fig. 1. The schematic illustration for oxidation reaction of SiC. 
liquid/powders $=3$ ) for $2 \mathrm{~h}$ with a constant speed of 400 $\mathrm{rpm}$ and then dried at $100^{\circ} \mathrm{C}$ for $10 \mathrm{~h}$. The specific content of each sample was listed in Table 2. Later, the resulting powders were ground in an agate mortar and sieved through a 60 -mesh sieve. The green bodies with $25 \mathrm{~mm}$ in diameter and $8 \mathrm{~mm}$ in thickness were formed by drypressing the compound powders at $15 \mathrm{MPa}$. Finally, the green bodies were fired in an electric furnace in air atmosphere at $1080-1240^{\circ} \mathrm{C}$ for $30 \mathrm{~min}$ at a heating rate of $5^{\circ} \mathrm{C} / \mathrm{min}$.

\subsection{Test and characterization}

The composition of the ceramic tile polishing waste powders was measured with a silicate chemical compo-

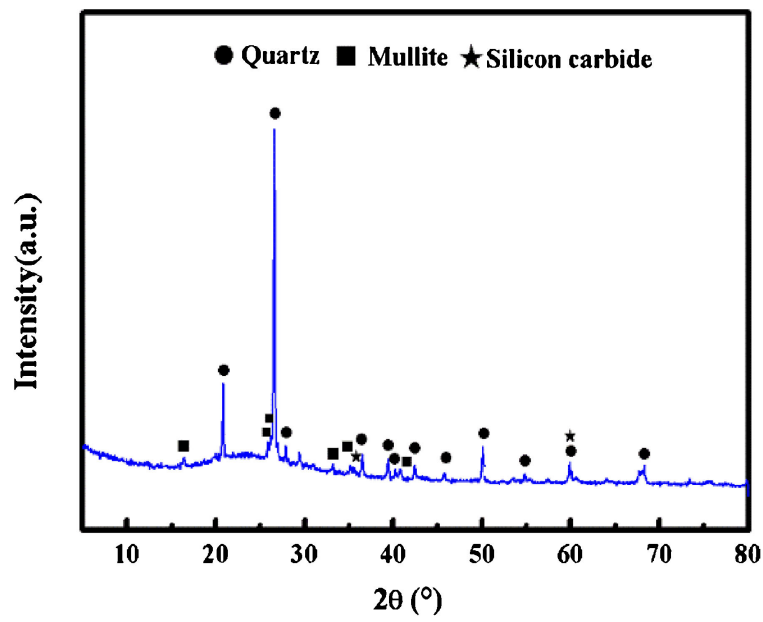

Fig. 2. The XRD pattern of CTPW.

Table 2. The weight ration of samples (wt \%)

\begin{tabular}{ccc}
\hline & Raw material \\
Sample NOs. & 100 & $\left(\mathrm{NH}_{4}\right)_{6} \mathrm{Mo}_{7} \mathrm{O}_{24}$ \\
\hline S0 & 99 & 0 \\
S1 & 98 & 1 \\
S2 & 96 & 2 \\
S4 & 94 & 4 \\
S6 & 6 \\
\hline
\end{tabular}

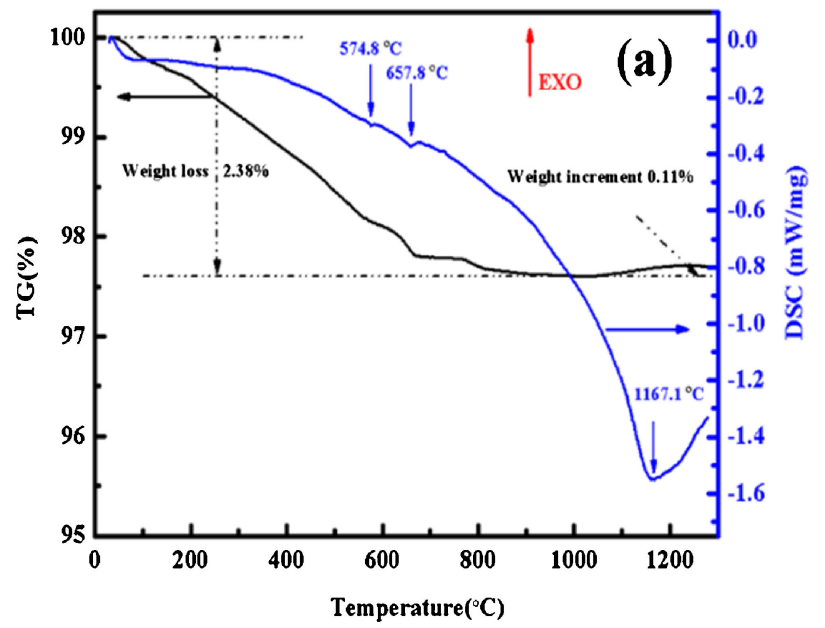

sition analysis instrument (DHF86, Xiangtan Songshan instrument Co. Ltd., China). The phase identification of the sintering specimens was performed by an X-ray diffractometer (XRD; X'Pert Pro, PANalytical Co., Holland) using $\mathrm{CuK} \alpha$ radiation at room temperature over a $2 \theta$ angle scan range of 5 to $80^{\circ}$. The microstructure of the sintered specimens were analyzed by scanning electron microscopy (SEM; Model EVO18, ZEISS, Germany). The macrostructure of the sintered specimens was analyzed by stereomicroscope (SZX 10-3121, OLYMPUS, Japan). The image analysis software (Image-Pro Plus6.0, Media Cybernetics, USA) was used to determine the pore size of the fired body. The bulk density and open porosity of the sintered samples were measured according to the ASTM C373-88. The compressive strength was measured by using a universal electronic tester (CMT4304) with load rate of $0.5 \mathrm{~mm} / \mathrm{min}$. The final result represented the average of 5 individual tests. Thermal behavior was examined by a thermogravimetry-differential scanning calorimetry instrument (TG-DSC; NETZSCH STA449C, Germany), and was carried out in $\mathrm{Al}_{2} \mathrm{O}_{3}$ crucibles at a heating rate of $10^{\circ} \mathrm{C} / \mathrm{min}$ in air and reached a final temperature of $1280^{\circ} \mathrm{C}$.

\section{Results and discussion}

\subsection{Thermal analysis}

Figure 3 shows the TG-DSC curves of the samples S0 and $\mathrm{S} 2$ from 40 to $1280^{\circ} \mathrm{C}$ in air atmosphere. For two samples, there existed three endothermic peaks, respectively. The endothermic peaks at around $574^{\circ} \mathrm{C}$ in two samples was attributed to the crystal transformation $(\beta$ quartz to $\alpha$-quartz). For sample S0 [as shown in Fig. 3(a)], the weight loss of $2.38 \%$ in $40-1049^{\circ} \mathrm{C}$ was due to the loss of water and the decomposition of impurities correlating with the second endothermic peak at $647^{\circ} \mathrm{C}$. For sample S2 [as shown in Fig. 3(b)], the weight loss of $2.17 \%$ in $40-1000^{\circ} \mathrm{C}$ was related to the loss of water, the decomposition of $\left(\mathrm{NH}_{4}\right)_{6} \mathrm{Mo}_{7} \mathrm{O}_{24}$ correlating with the first endothermic peak at $315^{\circ} \mathrm{C}$ and the decomposition of impurities, respectively. ${ }^{30)}$ Besides, it could be seen that there

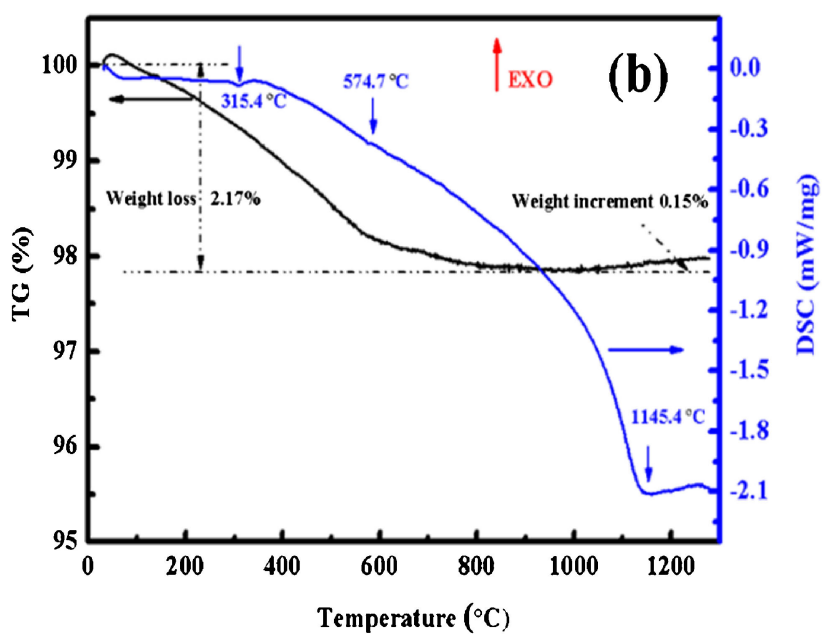

Fig. 3. The TG-DSC results of samples: (a) S0 and (b) S2 sintered at air atmosphere. 
was a slight weight increment of $0.11 \%$ from 1049 to $1280^{\circ} \mathrm{C}$ in sample $\mathrm{S} 0$ and $0.15 \%$ from 1000 to $1280^{\circ} \mathrm{C}$ in sample S2, which was caused by the oxidation of SiC. The last pronounced endothermic peak appeared at $1167^{\circ} \mathrm{C}$ for the sample S0 while at $1145^{\circ} \mathrm{C}$ for the sample S2, which was associated to the formation of liquid phase. ${ }^{16), 31 \text { ) }}$

There were some significant differences in two samples because of adding $\left(\mathrm{NH}_{4}\right)_{6} \mathrm{Mo}_{7} \mathrm{O}_{24}$. The weight loss in sample $\mathrm{S} 2$ was less than that in sample $\mathrm{S} 0$, which indicated that the sublimation of $\mathrm{MoO}_{3}$ obtained from decomposition of $\left(\mathrm{NH}_{4}\right)_{6} \mathrm{Mo}_{7} \mathrm{O}_{24}$ was not happened and may be restrained by the existence of $\mathrm{CaO}$ or $\mathrm{CaCO}_{3}$ in CTPW. ${ }^{32), 33)}$ In addition, the initial temperature of weight increment (about $1000^{\circ} \mathrm{C}$ ) that may be the starting temperature of $\mathrm{SiC}$ oxidation reaction in sample $\mathrm{S} 2$ were lower than that in sample S0. This variation showed that the $\mathrm{MoO}_{3}$ (like alkali metal oxide or alkali earth metal oxide) could promote the formation of liquid phase in a lower temperature. ${ }^{24)}$

\subsection{Sintering properties}

Figure 4 shows the effects of the addition amounts of $\left(\mathrm{NH}_{4}\right)_{6} \mathrm{Mo}_{7} \mathrm{O}_{24}$ on the bulk density of sample S0 to S6

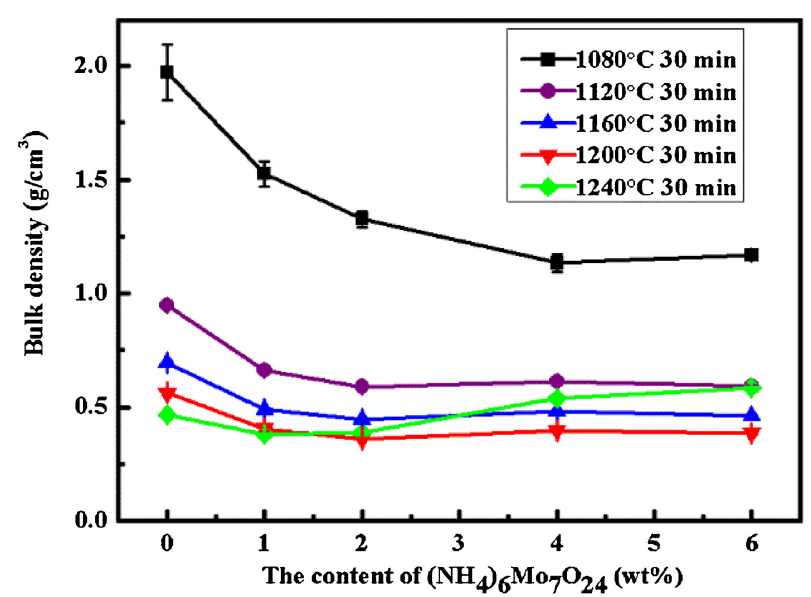

Fig. 4. The bulk density of samples with different $\left(\mathrm{NH}_{4}\right)_{6}$ $\mathrm{Mo}_{7} \mathrm{O}_{24}$ addition (sample $\mathrm{S} 0$ to $\mathrm{S} 6$ ).

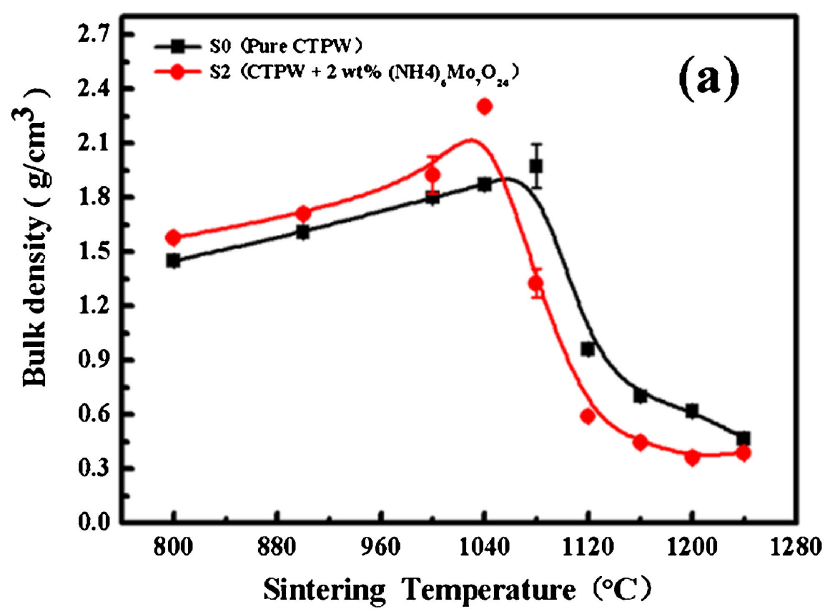

sintered at different temperature for $30 \mathrm{~min}$. for sample S0 with no $\left(\mathrm{NH}_{4}\right)_{6} \mathrm{Mo}_{7} \mathrm{O}_{24}$ addition, the bulk density showed a lower value compared to sample S1 to S6 with $\left(\mathrm{NH}_{4}\right)_{6} \mathrm{Mo}_{7} \mathrm{O}_{24}$ addition. The reason of this phenomenon was the low oxidation reaction rate of $\mathrm{SiC}$ in $\mathrm{CTPW}$, which caused less gases production. Thus, adding the sintering aid of $\left(\mathrm{NH}_{4}\right)_{6} \mathrm{Mo}_{7} \mathrm{O}_{24}$ was necessary for obtaining foam ceramic with low bulk density. In the temperature of $1080^{\circ} \mathrm{C}$, it was clearly found that the bulk density of the sample (S0-S4) gradually decreased from 1.97 to 1.13 $\mathrm{g} / \mathrm{cm}^{3}$ with the amounts of $\left(\mathrm{NH}_{4}\right)_{6} \mathrm{Mo}_{7} \mathrm{O}_{24}$ increasing from 0 to $4 \mathrm{wt} \%$ but showed a slight rise in the sample S6 (1.16 $\left.\mathrm{g} / \mathrm{cm}^{3}\right)$. It was worthy to note that there existed a similar tendency when the temperature increased from 1120 to $1200^{\circ} \mathrm{C}$. However, the bulk density of the sample S2 to S6 was almost nothing changed. This trend illustrated that the moderate addition of $\left(\mathrm{NH}_{4}\right)_{6} \mathrm{Mo}_{7} \mathrm{O}_{24}(2 \mathrm{wt} \%)$ in CTPW for the foaming of sample, while the excessive $\left(\mathrm{NH}_{4}\right)_{6} \mathrm{Mo}_{7} \mathrm{O}_{24}$ addition had small influence on the bulk density of sample. These results was due to the content of liquid phase increased with the $\left(\mathrm{NH}_{4}\right)_{6} \mathrm{Mo}_{7} \mathrm{O}_{24}$ addition raised, and this caused more oxidation of $\mathrm{SiC}$. Then more gas production resulted in generating more big pores. In addition, the bulk density of the sample S0 to S6 gradually decreased with the sintering temperature increasing. However, upon further increasing the sintering temperature to $1240^{\circ} \mathrm{C}$, the bulk density of the sample S2 to S6 increased gradually and showed a great value compared to former sintering temperature. The reason for these variations may be that the viscosity of silicate liquid was relatively low at excessive temperature after adding the $\left(\mathrm{NH}_{4}\right)_{6} \mathrm{Mo}_{7} \mathrm{O}_{24}$. A part of pores in CTPW may fracture and connect with each other under this viscosity. Then a small number of open pores could be obtained, leading to the increase of bulk density. Therefore, the $\left(\mathrm{NH}_{4}\right)_{6} \mathrm{Mo}_{7} \mathrm{O}_{24}$ addition of $2 \mathrm{wt} \%$ and sintering temperature of $1200^{\circ} \mathrm{C}$ was most suitable, which showed the lowest value of $0.362 \mathrm{~g} / \mathrm{cm}^{3}$.

The effect of sintering temperature on samples was further researched. The results were shown in Figs. 5(a) and 5(b), and it was indicated the bulk densities and open porosities of sample S0 and S2 sintered at a temperature

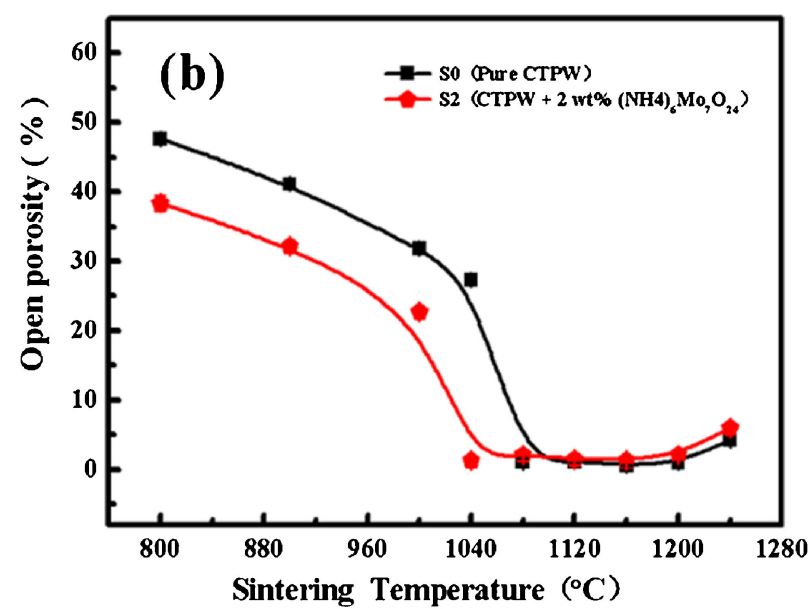

Fig. 5. (a) The bulk density and (b) open porosity of samples sintered at various temperature. 
range from 800 to $1240^{\circ} \mathrm{C}$. In Fig. 5(a), a first rises and then falls trend could be seen in both sample S0 and S2. However, from Fig. 5(b), it can be seen that the open porosities of sample S0 and S2 changed in the opposite trend. Thus, the sintering process could be divided into two stages. The first stage was sintering densification process that was from 800 to $1080^{\circ} \mathrm{C}$ for sample S0 and from 800 to $1040^{\circ} \mathrm{C}$ for sample S2. At this stage, the densification degree of samples increased with more generation of silicate liquid phase, but the bulk densities of sample S2 were all greater than sample S0 before reaching the maximum value. Moreover, the bulk density of sample $\mathrm{S} 2$ achieved a maximum value in advance compared to sample S0. Similarly, the open porosities of sample S2 were all less than sample S0 before reaching a lower value in advance. This phenomenon could be explained by the addition of $\left(\mathrm{NH}_{4}\right)_{6} \mathrm{Mo}_{7} \mathrm{O}_{24}$ which could promote the formation of silicate liquid phase in a lower temperature. The increase of liquid phase further enhanced the densification process by filling the clearance between solid grains. In the second stage, the value of bulk density sharply dropped in two samples, but the value of open porosity only showed a slight increase in two samples. The reason for this was due to the more generation of silicate liquid phase with the sintering temperature increased, and then the $\mathrm{SiO}_{2}$ protective layer of $\mathrm{SiC}$ was destroyed. The $\mathrm{SiC}$ inside $\mathrm{CTPW}$ could react with $\mathrm{O}_{2}$, which caused the gas of $\mathrm{CO}_{2}$ or $\mathrm{CO}$ released. These gases fixed in the liquid phase caused the formation of closed pores and prevent to the densification of samples. Furthermore, these closed pores began to grow because the pressure inside pores increased with the increasing temperature. ${ }^{16)}$ Thus, the bulk densities got a decrease at the same time but the open porosities changed a little and had little difference in two samples. However, the values of bulk density in sample $\mathrm{S} 2$ were all less than sample $\mathrm{S} 0$. This difference between $\mathrm{S} 0$ and $\mathrm{S} 2$ was also due to the addition of $\left(\mathrm{NH}_{4}\right)_{6} \mathrm{Mo}_{7} \mathrm{O}_{24}$. The oxidation of $\mathrm{SiC}$ was mainly depended on amount of liquid phase in the sintering process of CTPW. The effect of $\mathrm{MoO}_{3}$ on the generation of liquid phase was obvious in first stage, so it was also more effective at higher temperatures. Therefore, more gases released and then the closed pores might burst and connect with each other [as seen in Fig. 8(e)] that was caused by the more oxidation of $\mathrm{SiC}$, which caused a lower value of bulk density and a slight increase of open porosities in the subsequent sintering temperature. Similarly, the slight increase of open porosities in sample S0 might be caused by the burst and connection of closed pores in higher temperature.

\subsection{Structural observations}

Figure 6 shows optical images of cross section of sample S0 to S6 fired at $1200^{\circ} \mathrm{C}$ for $30 \mathrm{~min}$ with different amounts of $\left(\mathrm{NH}_{4}\right)_{6} \mathrm{Mo}_{7} \mathrm{O}_{24}$. It can be seen that the porous structure or foam structure and many closed pores existed in all samples because of the oxidation reaction of $\mathrm{SiC}$ and generation of gas $\left(\mathrm{CO}\right.$ and $\left.\mathrm{CO}_{2}\right)$. The distribution of pore size, especially in sample $\mathrm{S} 1$ and $\mathrm{S} 2$, was relative uniform with adding the $\left(\mathrm{NH}_{4}\right)_{6} \mathrm{Mo}_{7} \mathrm{O}_{24}$. Moreover, it was obviously found that the average pore size increased a lot (from 0.58 to $1.21 \mathrm{~mm}$, as observed in Fig. 7) and the pore wall increased as well with increasing the amounts of $\left(\mathrm{NH}_{4}\right)_{6} \mathrm{Mo}_{7} \mathrm{O}_{24}$. These results were probably due to that the $\mathrm{MoO}_{3}$, decomposed from $\left(\mathrm{NH}_{4}\right)_{6} \mathrm{Mo}_{7} \mathrm{O}_{24}$, caused the formation of liquid glassy phase at a lower temperature and reduced the viscosity of the liquid phase, which could lead to a more oxidation reaction of $\mathrm{SiC}$ and accelerated the diffusion of gas. While the excess of liquid phase gen-

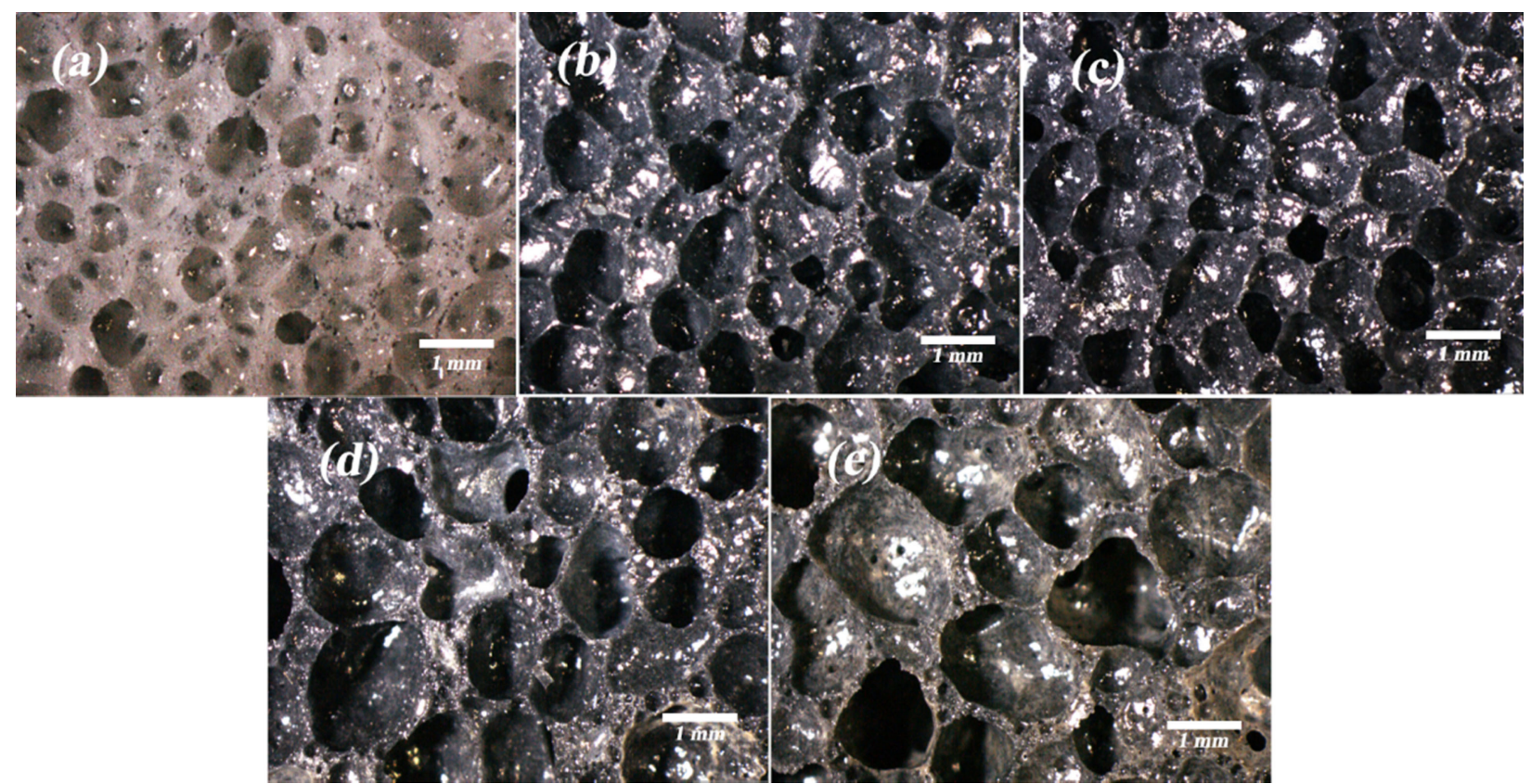

Fig. 6. The optical images of cross section of samples fired at $1200^{\circ} \mathrm{C}$ for $30 \mathrm{~min}$ with different $\left(\mathrm{NH}_{4}\right)_{6} \mathrm{Mo}_{7} \mathrm{O}_{24}$ addition: (a) S0: $0 \mathrm{wt} \%$, (b) S1: $1 \mathrm{wt} \%$, (c) S2: $2 \mathrm{wt} \%$, (d) S4: $4 \mathrm{wt} \%$, (e) S6: $6 \mathrm{wt} \%$. 
erated with adding excessive $\left(\mathrm{NH}_{4}\right)_{6} \mathrm{Mo}_{7} \mathrm{O}_{24}$, it resulted in greater pore size and pore wall, destruction of pores and increase of bulk density. Thus, adding the proper amounts of $\left(\mathrm{NH}_{4}\right)_{6} \mathrm{Mo}_{7} \mathrm{O}_{24}$ allowed obtaining a lower bulk density, greater pore size and more homogeneous porous structure.

Figure 8 shows the optical images of cross section of the sample S2 sintered from 1080 to $1240^{\circ} \mathrm{C}$ for $30 \mathrm{~min}$. It was evident in the images shown by Figs. 8(a)-8(e) that these samples had a porous structure in all sintering temperature, even in a low temperature $1080^{\circ} \mathrm{C}$ but the difference could be found in the pore size. As shown in Fig. 9, an obvious increase of pore size (from 0.08 to $2.15 \mathrm{~mm}$ ) happened as the sintering temperature increased. The reason for this was that amount of liquid phase increased with the increasing sintering temperature, and this could destroy the $\mathrm{SiO}_{2}$ protective layer. The gas caused by the oxidation

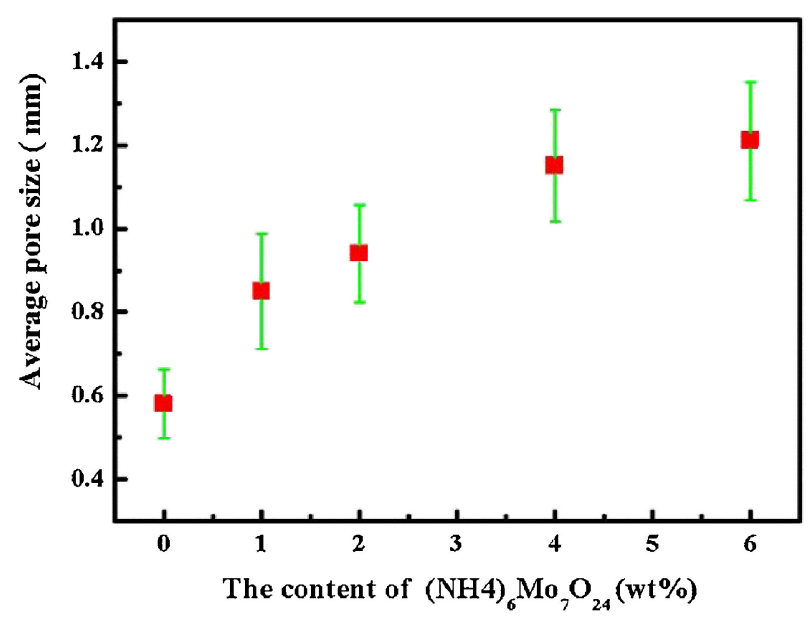

Fig. 7. The average pore size of samples fired at $1200^{\circ} \mathrm{C}$ for 30 min with different $\left(\mathrm{NH}_{4}\right)_{6} \mathrm{Mo}_{7} \mathrm{O}_{24}$ addition (sample $\mathrm{S} 0$ to $\mathrm{S} 6$ ). reaction of $\mathrm{SiC}$ would stay in the liquid phase, which could exert a pressure $(\mathrm{Pg})$ on the pore wall. The pressure $(\mathrm{Pg})$ inside pores increased with the increasing temperature, and the pores began to grow at the same time. ${ }^{16)}$ However, the pore could burst and connect with each other in a higher temperature [as seen in Fig. 6(e)], and it caused a greater pore size and an increase of bulk density. Thus, the optimum sintering temperature was $1200^{\circ} \mathrm{C}$.

Figure 10 shows the SEM images of cross section of sample S2 fired at $1200^{\circ} \mathrm{C}$ for $30 \mathrm{~min}$. Figure 10 (a) indicated that the microstructure of the sample and the microstructure of the inside pore wall was seen in Fig. 10(b). There existed a homogeneous porous structure and contained some small pores in pore wall or inside pore. From Fig. 10(b), it can be seen that some whiskers formed inside pore wall after magnification. The variation was due to that

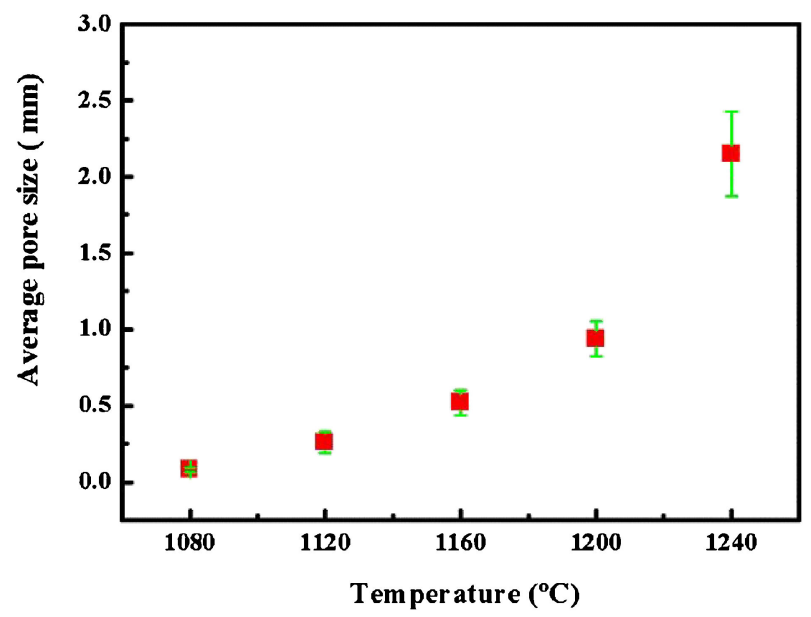

Fig. 9. The average pore size of samples $\mathrm{S} 2$ sintered at different temperature for $30 \mathrm{~min}$.

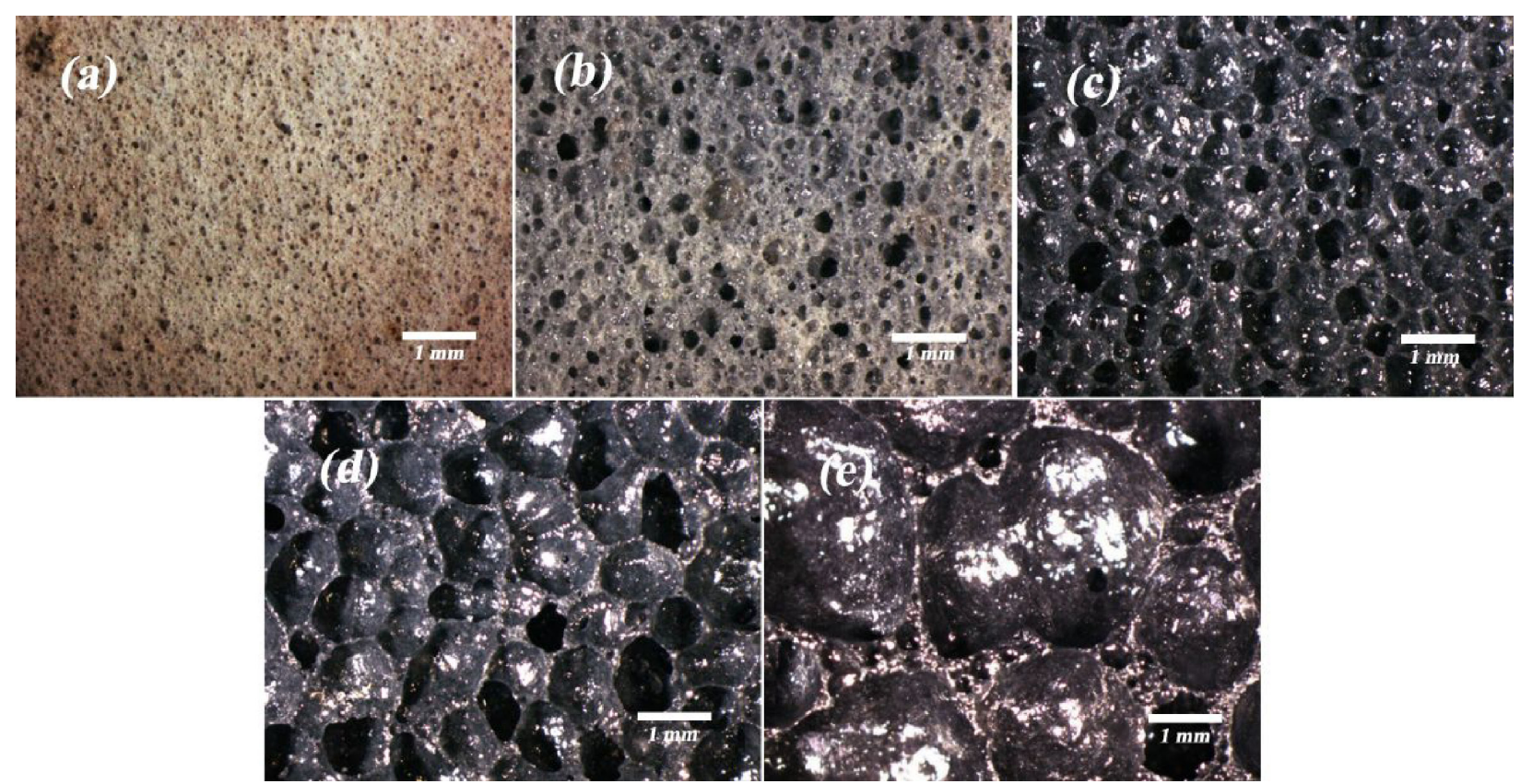

Fig. 8. The optical images of cross section of samples $\mathrm{S} 2$ sintered at different temperature for $30 \mathrm{~min}$ : (a) $1080^{\circ} \mathrm{C}$, (b) $1120^{\circ} \mathrm{C}$, (c) $1160^{\circ} \mathrm{C}$, (d) $1200^{\circ} \mathrm{C}$, (e) $1240^{\circ} \mathrm{C}$. 

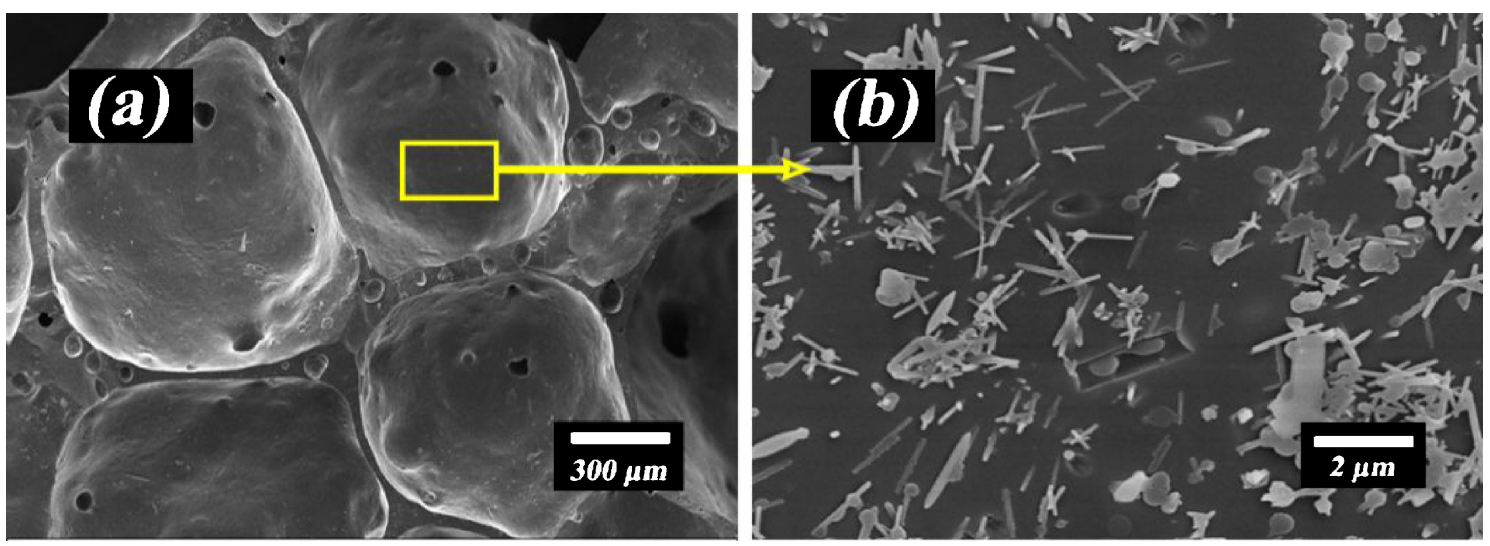

Fig. 10. The SEM images of cross section of samples S2 fired at $1200^{\circ} \mathrm{C}$ for $30 \mathrm{~min}$.

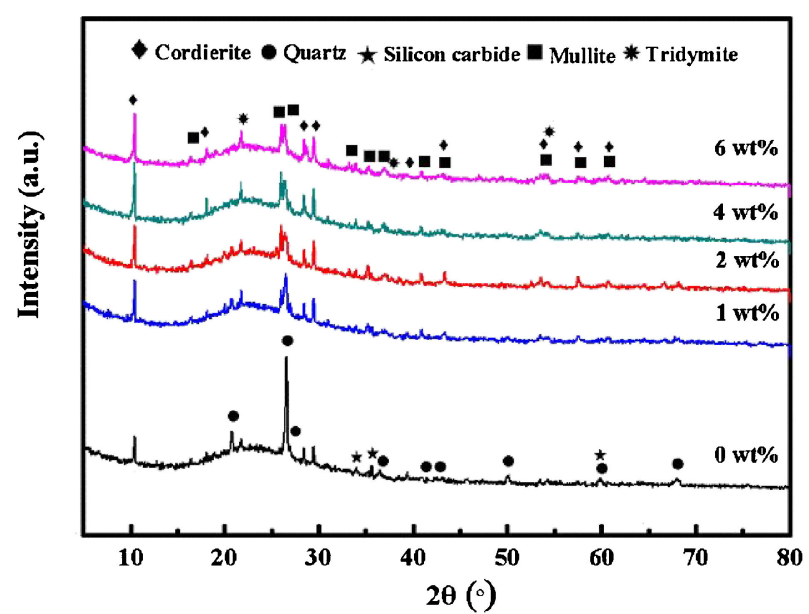

Fig. 11. The XRD results of samples fired at $1200^{\circ} \mathrm{C}$ for $30 \mathrm{~min}$ with different $\left(\mathrm{NH}_{4}\right)_{6} \mathrm{Mo}_{7} \mathrm{O}_{24}$ addition (sample $\mathrm{S} 0$ to $\mathrm{S} 6$ ).

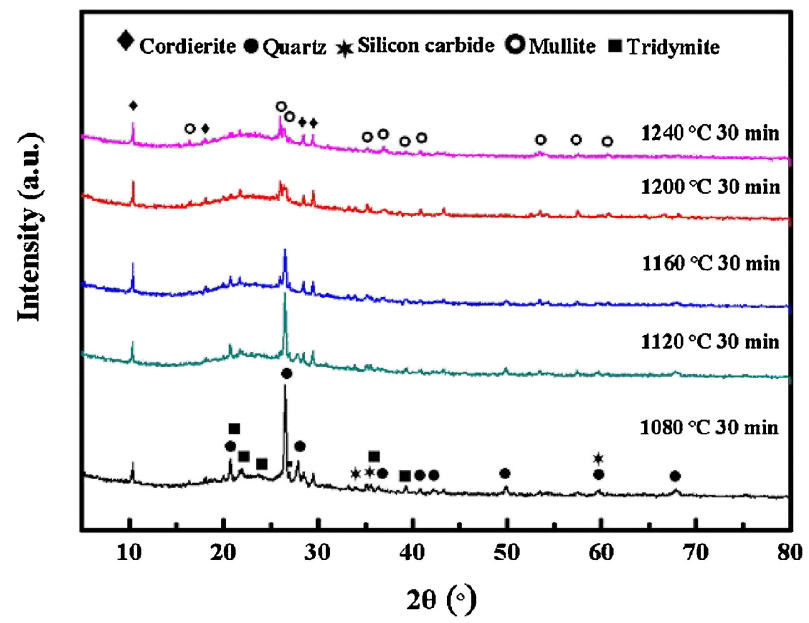

Fig. 12. The XRD results of samples S2 sintered at different temperature for $30 \mathrm{~min}$.

adding $\left(\mathrm{NH}_{4}\right)_{6} \mathrm{Mo}_{7} \mathrm{O}_{24}$, as a catalyst, could motivate in situ formation of whiskers. ${ }^{29)}$ In addition, these whiskers could be the mullite (as observed in Figs. 11 and 12).

\subsection{XRD analyses}

The XRD results of sample S0 to S6 fired at $1200^{\circ} \mathrm{C}$

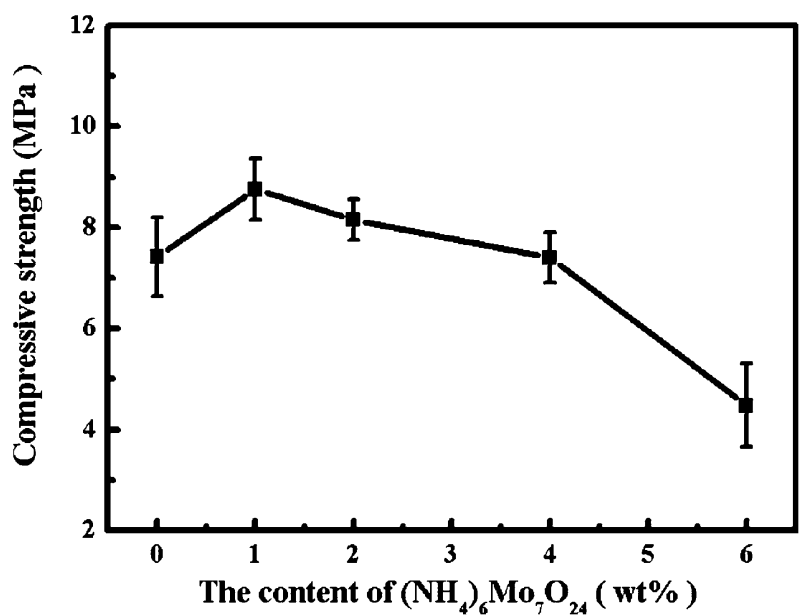

Fig. 13. The compressive strength of samples fired at $1200^{\circ} \mathrm{C}$ for $30 \mathrm{~min}$ with different $\left(\mathrm{NH}_{4}\right)_{6} \mathrm{Mo}_{7} \mathrm{O}_{24}$ addition (sample S0 to S6).

for 30 min with different amounts of $\left(\mathrm{NH}_{4}\right)_{6} \mathrm{Mo}_{7} \mathrm{O}_{24}$ were shown in Fig. 11. The shape of the peaks demonstrated that all the samples consisted of crystalline and amorphous phase corresponding to a board background. It was clearly found that the main crystalline phases were quartz and cordierite in sample doped without $\left(\mathrm{NH}_{4}\right)_{6} \mathrm{Mo}_{7} \mathrm{O}_{24}$, meanwhile a few weak peaks of mullite, silicon carbide and tridymite can be also seen. After $1 \mathrm{wt} \%\left(\mathrm{NH}_{4}\right)_{6} \mathrm{Mo}_{7} \mathrm{O}_{24}$ was introduced, the diffraction intensities of quartz and silicon carbide decreased obviously, and the intensities of mullite and cordierite increased. When the addition amount of $\left(\mathrm{NH}_{4}\right)_{6} \mathrm{Mo}_{7} \mathrm{O}_{24}$ was further increased from 2 to $6 \mathrm{wt} \%$, the obvious peak of quartz $\left(2 \theta \approx 20.5\right.$ and $\left.26^{\circ}\right)$ even disappeared and only phases of mullite and cordierite were observed. Based on the above analysis of these results, it was concluded that the addition of $\left(\mathrm{NH}_{4}\right)_{6} \mathrm{Mo}_{7} \mathrm{O}_{24}$ played an important role in the sintering process of foam ceramics. The melting of $\mathrm{MoO}_{3}$ could promote formation of mullite, which can enhance the mechanical properties (as shown in Fig. 13).

The XRD results of sample S2 sintered at different temperature for 30 min was presented in Fig. 12. Obviously, the XRD patterns of all samples consisted of a board 
background peak corresponding to the amorphous phase. With increasing the sintering temperature from 1080 to $1160^{\circ} \mathrm{C}$ for $30 \mathrm{~min}$, the main crystalline phases were quartz and cordierite as well as including a few phases of mullite, silicon carbide and tridymite. However, the diffraction intensities of quartz $\left(2 \theta \approx 20.5,26\right.$ and $\left.27.8^{\circ}\right)$ gradually decreased as the sintering temperature increased. When the sintering temperature further raised to 1200 and $1240^{\circ} \mathrm{C}$, the peaks of quartz disappeared but the peaks of mullite became more obvious. Hence, increasing the sintering temperature was also favorable for the formation of mullite. Moreover, the phase of tridymite may come from the crystal transformation ( $\alpha$-quartz to $\beta$ - tridymite). This transformation caused volume expension of $16 \%$. If this change happened in the $\mathrm{SiO}_{2}$ protective layer of $\mathrm{SiC}$, the oxidation reaction rate could be accelerated due to the $\mathrm{SiC}$ inside directly reacted with $\mathrm{O}_{2}$. ${ }^{16}$ )

\subsection{Mechanical properties}

The results obtained from measurements of compressive strength with the different contents of $\left(\mathrm{NH}_{4}\right)_{6} \mathrm{Mo}_{7} \mathrm{O}_{24}$ were plotted in Fig. 13. These results showed that the compressive strength increased first and then decreased when the $\left(\mathrm{NH}_{4}\right)_{6} \mathrm{Mo}_{7} \mathrm{O}_{24}$ was introduced. The highest value of $8.76 \mathrm{MPa}$ was the sample $\mathrm{S} 1$. When the content of $\left(\mathrm{NH}_{4}\right)_{6} \mathrm{Mo}_{7} \mathrm{O}_{24}$ increased up to $2 \mathrm{wt} \%$, the compressive strength of sample decreased slightly $(8.16 \mathrm{MPa})$ because of a greater pore size. Even in the sample with $6 \mathrm{wt} \%$ $\left(\mathrm{NH}_{4}\right)_{6} \mathrm{Mo}_{7} \mathrm{O}_{24}$, the compressive strength still was 4.48 $\mathrm{MPa}$. Moreover, the bulk density of these samples was all less than $0.5 \mathrm{~g} / \mathrm{cm}^{3}$ (as shown in Fig. 4). The enhancement of compressive strength was associated with the formation of many mullite whiskers inside the pore wall (as observed in Figs. 10 and 11). In addition, the mechanical properties of foam ceramics were significantly influenced by the porous structure such as pore size and thickness of pore wall. The compressive strength decreased gradually of the sample S1 to S6, which resulted from the increasing of pore size. The effects of sintering temperature on the compressive strength was presented in Fig. 14. It was clearly

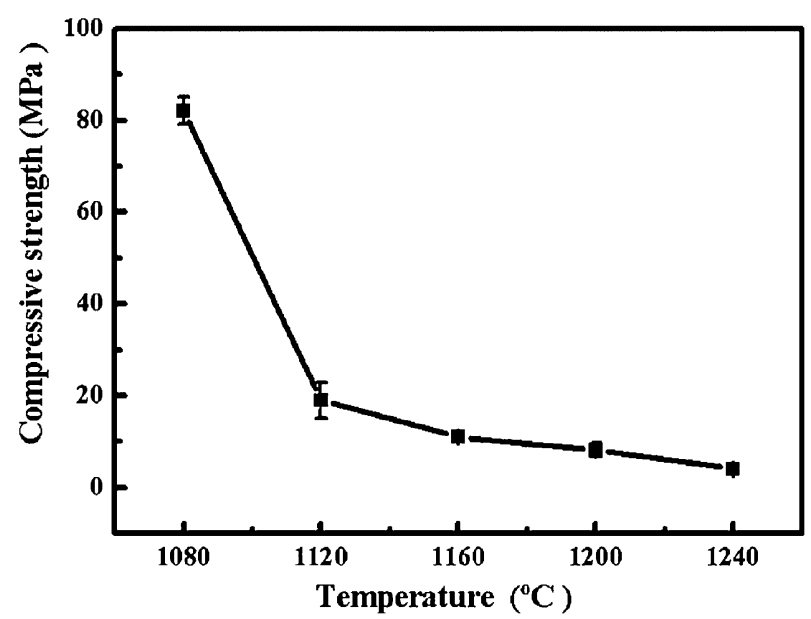

Fig. 14. The compressive strength of samples S2 sintered at different temperature for $30 \mathrm{~min}$. seen that the compressive strength declined sharply with the temperature increasing from 1080 to $1120^{\circ} \mathrm{C}$ (from 82.17 to $18.94 \mathrm{MPa}$ ). After rising to a higher temperature, the downward trend of the compressive strength was slowing down. The changing tendency was contrary to the changes in average pore size (as shown in Fig. 9).

\section{Conclusions}

The foam ceramics were fabricated by a simple solid phase sintering method, using CTPW as the main raw material, $\mathrm{SiC}$ inside the $\mathrm{CTPW}$ as foam agent and the $\left(\mathrm{NH}_{4}\right)_{6} \mathrm{Mo}_{7} \mathrm{O}_{24}$ as additive, which presented a typical closed-pore structure. The addition amounts of $\left(\mathrm{NH}_{4}\right)_{6-}$ $\mathrm{Mo}_{7} \mathrm{O}_{24}$ and sintering temperature exerted an effect on the bulk density, open porosity, structure, pore size, phase composition and compressive strength of the foam ceramics. Adding $\left(\mathrm{NH}_{4}\right)_{6} \mathrm{Mo}_{7} \mathrm{O}_{24}$ could decrease the viscosity of the liquid phase and accelerate the diffusion of gases generated by oxidation reaction of $\mathrm{SiC}$, as well as promote the formation of mullite whiskers and then enhance the compressive strength. Increasing sintering temperature mainly caused a greater pore size and changed the phase composition in the foam ceramics. The foam ceramics doped with $2 \mathrm{wt} \%\left(\mathrm{NH}_{4}\right)_{6} \mathrm{Mo}_{7} \mathrm{O}_{24}$ and fired at $1200^{\circ} \mathrm{C}$ for 30 min displayed excellent properties: a low bulk density $\left(0.362 \mathrm{~g} / \mathrm{cm}^{3}\right)$, the appropriate pore size $(0.94 \mathrm{~mm})$, a uniform pore size distribution and a very high compressive strength $(8.16 \mathrm{MPa})$. Such high-strength ceramics foam could well apply in the building thermal insulation materials. In addition, it is believed that this simple method will have important scientific value and economic benefits on direct recycling of large amounts of ceramic tile polishing waste in the word.

Acknowledgements This work was supported by the National Natural Science Foundation of China (51772102), the Guangdong YangFan Innovative \& Entrepreneurial Research Team Program (2016YT03C327), the Project of Public Welfare Research and Ability Building of Guangdong (2015B010105009), China Postdoctoral Science Foundation (NO. 2018M643074).

\section{References}

1) E. Sánchez, J. García-Ten, V. Sanz and A. Moreno, Ceram. Int., 36, 831-845 (2010).

2) L. R. dos Santos Conserva, F. G. Melchiades, S. Nastri, A. O. Boschi, M. Dondi, G. Guarini, M. Raimondo and C. Zanelli, J. Eur. Ceram. Soc., 37, 333-342 (2017).

3) M. Dondi, G. Ercolani, G. Guarini, C. Melandri, M. Raimondo, E. Rocha e Almendra and P. M. Tenorio Cavalcante, J. Eur. Ceram. Soc., 25, 357-365 (2005).

4) I. M. Hutchings, K. Adachi, Y. Xu, E. Sánchez, M. J. Ibáñez and M. F. Quereda, J. Eur. Ceram. Soc., 25, 3151-3156 (2005).

5) X. A. Xi, A. Z. Shui, Y. F. Li, Y. M. Wang, H. Abe and M. Naito, J. Eur. Ceram. Soc., 32, 3035-3041 (2012).

6) N. K. Sharma, P. Kumar, S. Kumar, B. S. Thomas and R. C. Gupta, Constr. Build. Mater., 151, 158-163 (2017). 
7) Y. H. Cheng, F. Huang, G. L. Li, L. S. Xu and J. L. Hou, Constr. Build. Mater., 55, 440-446 (2014).

8) E. Rambaldi, L. Esposito, A. Tucci and G. Timellini, J. Eur. Ceram. Soc., 27, 3509-3515 (2007).

9) S. Ke, Y. Wang, Z. Pan, C. Ning and S. Zheng, J. Clean. Prod., 115, 238-244 (2016).

10) C. S. G. Penteado, E. Viviani de Carvalho and R. C. C. Lintz, J. Clean. Prod., 112, 514-520 (2016).

11) P. C. Jacoby and F. Pelisser, J. Clean. Prod., 100, 84-88 (2015).

12) H. Elçi, J. Clean. Prod., 112, $742-752$ (2016).

13) R. Ji, Z. Zhang, Y. He, L. Liu and X. Wang, Constr. Build. Mater., 85, 119-126 (2015).

14) Z. Y. Xian, L. K. Zeng, X. S. Cheng and H. Wang, J. Therm. Anal. Calorim., 122, 997-1004 (2015).

15) Y. Guo, Y. Zhang, H. Huang, X. Meng, Y. Liu, S. Tu and B. Li, Constr. Build. Mater., 125, 1093-1100 (2016).

16) H. Wang, Z. Chen, L. Liu, R. Ji and X. Wang, Ceram. Int., 44, 10078-10086 (2018).

17) N. M. Bobkova, S. E. Barantseva and E. E. Trusova, Glass Ceram.+, 64, 47-50 (2007).

18) Y. Xia, Y. Bai, X. Wu, D. Zhou, Z. Wang, X. Liu and J. Meng, Solid State Sci., 14, 805-808 (2012).

19) Y. Wang, D. F. Zhou, L. Chen, S. K. Xie, X. J. Liu and J. Meng, J. Alloy. Compd., 710, 748-755 (2017).

20) J. Wang, D. Zhou, Y. Wang, J. Meng and J. Zhang, Phase Transit., 91, 1277-1288 (2018).

21) S. Vidya, S. Solomon and J. K. Thomas, J. Mater.
Sci.-Mater. El., 26, 3243-3255 (2015).

22) Z. Xing, D. Xiang and Y. Ma, J. Eur. Ceram. Soc., 38, 4842-4849 (2018)

23) Sanjay, N. Kishore and A. Agarwal, J. Alloy. Compd., 487, 52-57 (2009).

24) D. Toloman, R. Ciceo-Lucacel, D. A. Magdas, A. Regos, A. R. Biris, C. Leostean and I. Ardelean, J. Alloy. Compd., 556, 67-70 (2013).

25) O. A. Zamyatin, A. D. Plekhovich, E. V. Zamyatina and A. A. Sibirkin, J. Non-Cryst. Solids, 452, 130-135 (2016).

26) G. Lakshminarayana, K. M. Kaky, S. O. Baki, A. Lira, P. Nayar, I. V. Kityk and M. A. Mahdi, J. Alloy. Compd., 690, 799-816 (2017).

27) K. H. Hua, A. Z. Shui, L. F. Xu, K. Zhao, Q. Zhou and X. A. Xi, Ceram. Int., 42, 6080-6087 (2016).

28) Z. Zhu, Z. Wei, J. Shen, L. Zhu, L. Xu, Y. Zhang, S. Wang and T. Liu, Ceram. Int., 43, 2871-2875 (2017).

29) W. Wang, W. Chen, H. Liu and C. Han, J. Alloy. Compd., 748, 876-881 (2018).

30) Y. Liu, P. Feng, Z. Wang, X. Jiao and F. Akhtar, Sci. Rep., 7, 1845-1856 (2017).

31) T. W. Cheng and Y. S. Chen, Ceram. Int., 30, 343-349 (2004).

32) R. Andruszkiewicz, J. Alloy. Compd., 186, 369-378 (1992).

33) H. Y. Zhu, R. Gao, W. T. Jin, L. W. Qiu and Z. L. Xue, Rare Metals, 37, 621-624 (2015). 